\title{
Serum suPAR and syndecan-4 levels predict severity of community-acquired pneumonia: a prospective, multi-centre study
}

Qiongzhen Luo, Pu Ning, Yali Zheng, Ying Shang, Bing Zhou and Zhancheng Gao*

\begin{abstract}
Background: Community-acquired pneumonia (CAP) is a major cause of death worldwide and occurs with variable severity. There are few studies focused on the expression of soluble urokinase-type plasminogen activator receptor (suPAR) and syndecan-4 in patients with CAP.
\end{abstract}

Methods: A prospective, multi-centre study was conducted between January 2014 and December 2016. A total of 103 patients with severe CAP (SCAP), 149 patients with non-SCAP, and 30 healthy individuals were enrolled. Clinical data were recorded for all enrolled patients. Serum suPAR and syndecan-4 levels were determined by quantitative enzyme-linked immunosorbent assay. The t test and Mann-Whitney $U$ test were used to compare between two groups; one-way analysis of variance and the Kruskal-Wallis test were used to compare multiple groups. Correlations were assessed using Pearson and Spearman tests. Area under the curve (AUCs), optimal threshold values, sensitivity, and specificity were calculated. Survival curves were constructed and compared by log-rank test. Regression analyses assessed the effect of multiple variables on 30-day survival.

Results: suPAR levels increased in all patients with CAP, especially in severe cases. Syndecan-4 levels decreased in patients with CAP, especially in non-survivors. suPAR and syndecan-4 levels were positively and negatively correlated with severity scores, respectively. suPAR exhibited high accuracy in predicting SCAP among patients with CAP with an AUC of $0.835(p<0.001)$. In contrast, syndecan-4 exhibited poor diagnostic value for predicting SCAP (AUC 0.550, $p=0.187$ ). The AUC for predicting mortality in patients with SCAP was 0.772 and 0.744 for suPAR and syndecan-4, respectively; the respective prediction threshold values were $10.22 \mathrm{ng} / \mathrm{mL}$ and $6.68 \mathrm{ng} / \mathrm{mL}$. Addition of both sUPAR and syndecan-4 to the Pneumonia Severity Index significantly improved their prognostic accuracy, with an AUC of 0.885 . Regression analysis showed that suPAR $\geq 10.22 \mathrm{ng} / \mathrm{mL}$ and syndecan $-4 \leq 6.68 \mathrm{ng} / \mathrm{mL}$ were reliable independent markers for prediction of 30-day survival.

Conclusion: suPAR exhibits high accuracy for both diagnosis and prognosis of SCAP. Syndecan-4 can reliably predict mortality in patients with SCAP. Addition of both suPAR and syndecan-4 to a clinical scoring method could improve prognostic accuracy.

Trial registration: ClinicalTrials.gov, NCT03093220. Registered on 28 March 2017 (retrospectively registered).

Keywords: suPAR, Syndecan-4, Community acquired pneumonia, Severity, Mortality

\footnotetext{
* Correspondence: zcgao@bjmu.edu.cn

Department of Respiratory \& Critical Care Medicine, Peking University

People's Hospital, Beijing, People's Republic of China
} 


\section{Background}

Community-acquired pneumonia (CAP) is a very common type of respiratory infection. Despite the rapid development of new treatments, pneumonia continues to cause a high rate of complications and associated costs, and remains a major international cause of death [1, 2]. Because of the diversity of clinical conditions and the lag in a clear definition of the causative pathogen, the most challenging task for a physician is the risk stratification of patients with CAP and the subsequent administration of individual treatment [3]. CURB-65 and the Pneumonia Severity Index (PSI) are widely recommended and validated scoring methods: CURB-65 is a predictive assessment that is concisely and conveniently implemented in clinical settings [4]. PSI is a sensitive indicator in judging whether patients should be hospitalized [4]. However, both the CURB-65 and PSI scores are neither comprehensive nor exhaustive. CURB-65 assesses very few aspects of disease with low specificity, while PSI relies primarily on age and underlying diseases such that it is inaccurate in young and otherwise healthy patients. In recent years, novel biomarkers, such as soluble triggering receptor expressed on myeloid cells-1 (sTREM-1) [5], proadrenomedullin (proADM) [6], and copeptin [7] have been widely validated in clinical settings. However, their sensitivity and specificity for prediction of pneumonia severity are variable and largely insufficient; thus, there is a need for new biomarkers to provide effective risk stratification and assist in clinical judgement.

Urokinase-type plasminogen activator receptor (uPAR) is a component of the plasminogen activator (PA) system. This system plays an important role in many physiological and pathological processes, including tissue remodelling [8], thrombosis [9], inflammation [10], and tumourigenesis [11]. The soluble form of UPAR (suPAR) can be detected in serum and other organic fluids [12]; its levels are increased in patients with HIV infection, malaria, tuberculosis, and sepsis, suggesting that it could serve as a useful prognostic biomarker [13]. This capability may be useful for prediction of the severity of CAP, but few studies have focused on suPAR levels in patients with CAP.

The syndecan proteins, a family of transmembrane heparan sulphate proteoglycans, bind to various extracellular effectors and regulate many processes, such as tissue homeostasis, inflammation, tumour invasion, and metastasis [14-16]. Syndecan-4 is the most wellknown member of the family. Studies have demonstrated that levels of syndecan-4 increase in response to bacterial inflammation, and that syndecan-4 possesses an anti-inflammatory function in acute pneumonia [17]. However, data on the relationship between the expression of syndecan-4 and the severity of CAP are rare.

Considering the previous experimental data on suPAR and syndecan-4, we hypothesized that their serum levels might be correlated with the severity and prognosis of CAP. Thus, the aim of this study was to clarify the precise roles of suPAR and syndecan-4 in CAP, and to validate the effectiveness of these proteins as indicators of the severity of CAP and of the risk of death in severe CAP.

\section{Methods}

\section{Study population}

This prospective, observational study was conducted during the period of January 2014 through December 2016 among patients hospitalized in Peking University People's Hospital, Tianjin Medical University General Hospital, Wuhan University People's Hospital, and Fujian Provincial Hospital (ClinicalTrials.gov ID, NCT03093220). All patients in this study were diagnosed with CAP.

CAP was defined by the following criteria [18]: (1) a chest radiograph showing either a new patchy infiltrate, leaf or segment consolidation, ground glass opacity, or interstitial change; (2) at least one of the following signs - (a) the presence of cough, sputum production, and dyspnoea; (b) core body temperature $>38.0{ }^{\circ} \mathrm{C}$; (c) auscultatory findings of abnormal breath sounds and rales; or (d) peripheral white blood cell counts $>10 \times$ $10^{9} / \mathrm{L}$ or $<4 \times 10^{9} / \mathrm{L}$; and (3) symptom onset that began in the community, rather than in a healthcare setting.

Severe CAP (SCAP) was diagnosed by the presence of at least one major criterion, or at least three minor criteria, as follows [19]. Major criteria: (1) requirement for invasive mechanical ventilation and (2) occurrence of septic shock with the need for vasopressors. Minor criteria: (1) respiratory rate $\geq 30$ breaths/min; (2) oxygenation index $\left(\mathrm{PaO}_{2} / \mathrm{FiO}_{2}\right) \leq 250$; (3) presence of multilobar infiltrates; (4) presence of confusion; (5) serum urea nitrogen $\geq 20 \mathrm{mg} / \mathrm{dL}$; (6) white blood cell count $\leq 4 \times 10^{9} / \mathrm{L}$; (7) blood platelet count $<100 \times 10^{9} / \mathrm{L}$; (8) core body temperature $<36.0{ }^{\circ} \mathrm{C}$; and (9) hypotension requiring aggressive fluid resuscitation.

The exclusion criteria were age $<18$ years, or the presence of any of the following: pregnancy, immunosuppressive condition, malignant tumour, end-stage renal or liver disease, active tuberculosis, or pulmonary cystic fibrosis.

\section{Sample size calculation}

In this study, we set the type I error/significance level (two-sided) at $\alpha=0.05$ and the type II error at $\beta=0.10$ to provide $90 \%$ power. The test standard deviation was $Z_{\alpha}=$ 1.96 and $Z_{\beta}=1.282$. Assuming the mortality of non-SCAP 
and SCAP was $P_{0}=0.05$ and $P_{1}=0.25$, respectively $[1,19]$, the sample size was calculated as follows:

$$
\begin{gathered}
R=\frac{P_{1}}{P_{0}} ; A=P_{1}\left(1-P_{0}\right)+P_{0}\left(1-P_{1}\right) ; \\
B=(R-1) P_{0}\left(1-P_{0}\right) ; \\
K=(A+B)(R A-B)-R\left(P_{1}-P_{0}\right)^{2} \\
\mathrm{~N}_{\text {non-SCAP }}^{\prime}=\frac{Z_{\beta}^{2} \mathrm{~K}+\mathrm{Z}_{\alpha}^{2}(\mathrm{~A}+\mathrm{B})^{2}+2 \mathrm{Z}_{\alpha} \mathrm{Z}_{\beta}(\mathrm{A}+\mathrm{B}) \sqrt{\mathrm{K}}}{\left(P_{1}-P_{0}\right)^{2}(\mathrm{~A}+\mathrm{B})}=121 \\
\mathrm{~N}_{\text {SCAP }}^{\prime}=\frac{\mathrm{N}_{\text {non-SCAP }}}{\mathrm{R}}=25
\end{gathered}
$$

The rate of ineligible inclusion was $10-30 \%$. The primary number of patients with non-SCAP was calculated as follows:

$$
\mathrm{N}_{\text {non-SCAP }}=\frac{\mathrm{N}_{\text {non }-\mathrm{SCAP}}^{\prime}}{1-30 \%}=173
$$

The primary number of patients with SCAP was calculated as follows:

$$
\mathrm{N}_{\mathrm{SCAP}}=\frac{\mathrm{N}^{\prime} \mathrm{SCAP}}{1-30 \%}=36
$$

We ultimately recruited 252 patients with CAP, including 103 with SCAP and 149 with non-SCAP. All patients with SCAP were admitted to the intensive care unit (ICU). The screening process is shown in Fig. 1. Thirty healthy people ( $>18$ years old, without any exclusionary diseases) served as a control group. All subjects provided informed consent. This study was approved by the medical ethics committee of Peking University People's Hospital.

\section{Blood sample collection}

Clinical data were recorded on all patients; these included whole blood leukocyte count (WBC), blood biochemical assessment, C-reactive protein (CRP), procalcitonin (PCT), blood gas analysis, and chest images. The confusion, urea, respiratory rate, blood pressure, and age $\geq 65$ years old (CURB-65) score [20], PSI [21], and Acute Physiology and Chronic Health Evaluation (APACHE) II [22] were calculated from clinical and laboratory data.

Peripheral venous blood samples were collected within 2 days after admission, in sterile, pro-coagulation tubes and centrifuged immediately; the resulting serum samples were stored at $-80{ }^{\circ} \mathrm{C}$ until analysis.

\section{Measurement of suPAR and syndecan-4}

Serum suPAR levels were measured using quantitative enzyme-linked immunosorbent assay (ELISA) kits (DUP00; R\&D Systems, Minneapolis, MN, USA) in duplicate as instructed by the manufacturer. Briefly, test wells containing serum samples, and standard wells containing a gradient

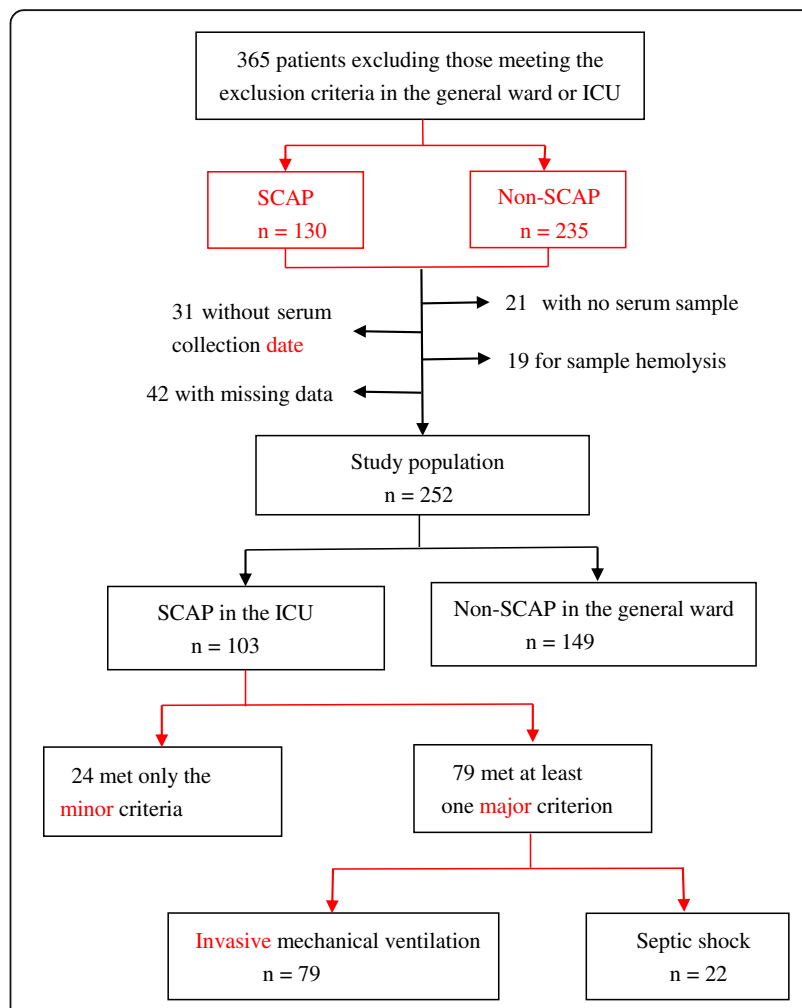

Fig. 1 Flowchart of the study population. SCAP severe community-acquired pneumonia

concentration of a standard protein, were analysed using a microplate assay. Absorbance at $450 \mathrm{~nm}$ was measured using the Multiskan FC (Thermo, Waltham, MA, USA). The detection sensitivity was $33 \mathrm{pg} / \mathrm{mL}$ and the intra-assay and inter-assay coefficients of variation were $<8 \%$. Serum syndecan-4 levels were determined using ELISA (JP27188; Immuno-Biological Laboratories, Fujioka, Japan) in duplicate as instructed by the manufacturer. Absorbance at $570 \mathrm{~nm}$ was measured using the Multiskan FC. The detection sensitivity was $3.94 \mathrm{pg} / \mathrm{mL}$ and the intra-assay and inter-assay coefficients of variation were $<5 \%$. Using the standard curve, the quantities of syndecan- 4 and suPAR were calculated using CurvExpert Professional 2.6.3 (Hyams Development, Madison, WI, USA).

\section{Statistical analysis}

Normally distributed continuous variables are expressed as means \pm standard error of the mean (SEM), abnormally distributed continuous variables are expressed as median (interquartile range) and categorical variables are expressed as number (percentage). For equivalent variables with a normal distribution, the independent Student's $t$ test was utilized to compare two groups. The Mann-Whitney U test was used to compare categorical variables and abnormal distributional variables between two groups. One-way analysis of variance and the 
Kruskal-Wallis test were used to compare multiple groups. Correlation between variables with normal distribution was assessed using Pearson's correlation test, while abnormal distributions were assessed using Spearman's rho test. Receiver operating characteristic (ROC) analysis was performed to differentiate patients with CAP from those with SCAP, and to separate nonsurvivors from the overall patients with SCAP. Areas under the curve (AUCs), optimal threshold values, sensitivity, and specificity were calculated. Kaplan-Meier methods were used to build 30-day survival curves, and survival rates were compared using the log-rank test. Cox proportional hazards regression analyses were used to analyse the effect of an array of variables on 30-day survival.

A two-sided $p$ value $<0.05$ was considered statistically significant; confidence intervals (CIs) were set at $95 \%$. Statistical analyses were performed by using GraphPad Prism version 6.01 software (GraphPad Software, La Jolla, CA, USA) and MedCalc statistical software version 15.2.2 (MedCalc Software, Ostend, Belgium).

\section{Results}

\section{Characteristics of the enrolled patients}

From January 2014 to December 2016, 252 patients (165 male, 87 female) were enrolled and divided into two groups (103 with SCAP and 149 with non-SCAP) according to their clinical characteristics. As shown in Table 1, there were no significant differences between the SCAP and non-SCAP groups in sex, past medical history, smoking, antibiotic pretreatment, and whether a causative pathogen was established. Chest radiographs revealed that $84.47 \%$ and $29.13 \%$ of patients with SCAP exhibited bilateral lung infection and pleural effusion, respectively; these proportions were significant higher than those observed in the non-SCAP group (29.53\% and $4.70 \%$, respectively; $p<0.001$ for both comparisons). Laboratory analyses showed that the SCAP group exhibited a higher WBC and higher neutrophil/lymphocyte ratio (NLR) than detected in the non-SCAP group $(p<$ 0.001 for both comparisons). Furthermore, serum CRP and PCT levels were substantially greater in the SCAP group than in the non-SCAP group $(p<0.001$ for both comparisons). The CURB-65, PSI, and APACHE II scores in the SCAP group were $1(0-2), 94.27 \pm 37.42$, and $15.18 \pm 5.65$, respectively. These scores were significantly higher than those of patients in the non-SCAP group $(0(0-1), 57.50$ (35.00-72.25), 8 (6-9), respectively; $p<0.001$ for all comparisons). The mortality rate in the SCAP group was $18.45 \%$, while no patients with non-SCAP died in hospital.

\section{Levels of suPAR and syndecan-4 in each group}

As shown in Fig. 2, serum suPAR level in healthy individuals was $1.71 \pm 1.00 \mathrm{ng} / \mathrm{mL}$, which was significantly lower than that in the non-SCAP group $(2.76(2.01-4.20) \mathrm{ng} / \mathrm{mL}$, $p<0.001)$. The SCAP group exhibited the highest
Table 1 Clinical characteristics and laboratory findings of the study population

\begin{tabular}{|c|c|c|c|}
\hline Characteristics & $\operatorname{SCAP}(n=103)$ & $\begin{array}{l}\text { Non-SCAP } \\
(n=149)\end{array}$ & $p$ value \\
\hline Age (years) & $56.14 \pm 17.32$ & $50(33-65)$ & 0.007 \\
\hline Male $(n)$ & $73(70.87 \%)$ & $92(61.74 \%)$ & 0.135 \\
\hline \multicolumn{4}{|c|}{ Past medical history } \\
\hline $\begin{array}{l}\text { Chronic heart } \\
\text { failure }\end{array}$ & $6(5.82 \%)$ & $9(6.04 \%)$ & 0.959 \\
\hline Diabetes mellitus & $12(11.65 \%)$ & $23(15.44 \%)$ & 0.394 \\
\hline $\begin{array}{l}\text { Cerebrovascular } \\
\text { disease }\end{array}$ & 17 (16.50\%) & $13(8.72 \%)$ & 0.061 \\
\hline $\begin{array}{l}\text { Chronic liver } \\
\text { disease }\end{array}$ & $7(6.80 \%)$ & $4(2.68 \%)$ & 0.063 \\
\hline COPD & 7 (6.80\%) & $5(3.35 \%)$ & 0.208 \\
\hline Smoking & $46(44.66 \%)$ & 76 (51.01\%) & 0.274 \\
\hline $\begin{array}{l}\text { Antibiotic pre- } \\
\text { treatment }\end{array}$ & $38(36.90 \%)$ & $71(47.65 \%)$ & 0.288 \\
\hline $\begin{array}{l}\text { Pathogen } \\
\text { established }\end{array}$ & $50(48.54 \%)$ & 65 (43.62\%) & 0.442 \\
\hline \multicolumn{4}{|l|}{ Chest x-ray } \\
\hline $\begin{array}{l}\text { Bilateral lung } \\
\text { infection }\end{array}$ & 87 (84.47\%) & 44 (29.53\%) & $<0.001$ \\
\hline Pleural effusion & $30(29.13 \%)$ & $7(4.70 \%)$ & $<0.001$ \\
\hline WBC $\left(\times 10^{9} / \mathrm{L}\right)$ & $10.05(6.80-15.21)$ & $7.49(5.52-10.79)$ & $<0.001$ \\
\hline NE\% & 84.00 (76.40-90.70) & 74.36 (63.95-81.68) & $<0.001$ \\
\hline LY\% & $8.70(5.05-14.20)$ & $16.30(9.72-27.05)$ & $<0.001$ \\
\hline NLR & $10.04(5.77-17.99)$ & $4.55(2.46-8.40)$ & $<0.001$ \\
\hline CRP (mg/L) & $107.10(26.00-189.00)$ & $46.16(9.19-108.7)$ & 0.001 \\
\hline $\mathrm{PCT}(\mu \mathrm{g} / \mathrm{L})$ & $0.54(0.20-3.43)$ & $0.14(0.05-0.64)$ & $<0.001$ \\
\hline CURB-65 & $1(0-2)$ & $0(0-1)$ & $<0.001$ \\
\hline PSI & $94 \pm 37$ & $58(35-72)$ & $<0.001$ \\
\hline APACHE II score & $15 \pm 6$ & $8(6-9)$ & $<0.001$ \\
\hline Total mortality & 19 (18.45\%) & $0(0 \%)$ & $<0.001$ \\
\hline 30-day mortality & $18(17.48)$ & $0(0 \%)$ & $<0.001$ \\
\hline
\end{tabular}

COPD chronic obstructive pulmonary disease, $W B C$ white blood cells, $N L R$ neutrophil/lymphocyte ratio, CRP C-reactive protein, $P C T$ procalcitonin, CURB65 confusion, urea, respiratory rate, blood pressure, and age $\geq 65$ years old, PSI Pneumonia Severity Index, APACHE II Acute Physiology and Chronic Health Evaluation II

level of suPAR, $6.17(4.37-9.72) \mathrm{ng} / \mathrm{mL}$ (compared with the non-SCAP level, $p<0.001)$. In patients with SCAP, the suPAR level of non-survivors was 13.19 (6.0518.68) $\mathrm{ng} / \mathrm{mL}$, which was notably higher than the suPAR level of survivors $(6.09(4.01-8.63) \mathrm{ng} / \mathrm{mL}, p<0.001)$.

In contrast, the expression of syndecan- 4 was reduced in patients with CAP. The level of syndecan-4 in healthy individuals was $14.30 \pm 5.34 \mathrm{ng} / \mathrm{mL}$, whereas in the SCAP and non-SCAP groups the levels were $9.54 \pm 5.92$ and $10.15 \pm 4.37 \mathrm{ng} / \mathrm{mL}$, respectively $(p<0.001$ for both comparisons). There was no difference in the levels of syndecan- 4 between the SCAP and non-SCAP groups 

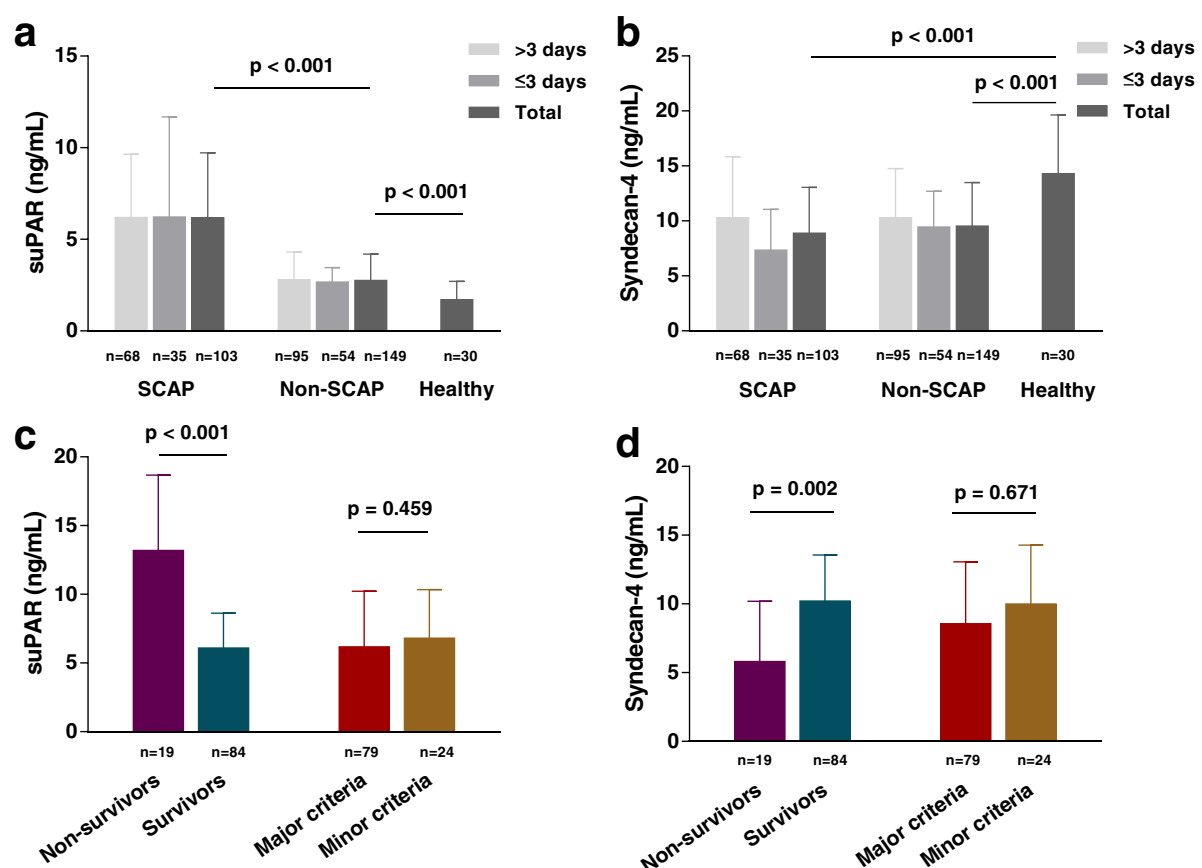

\section{d}
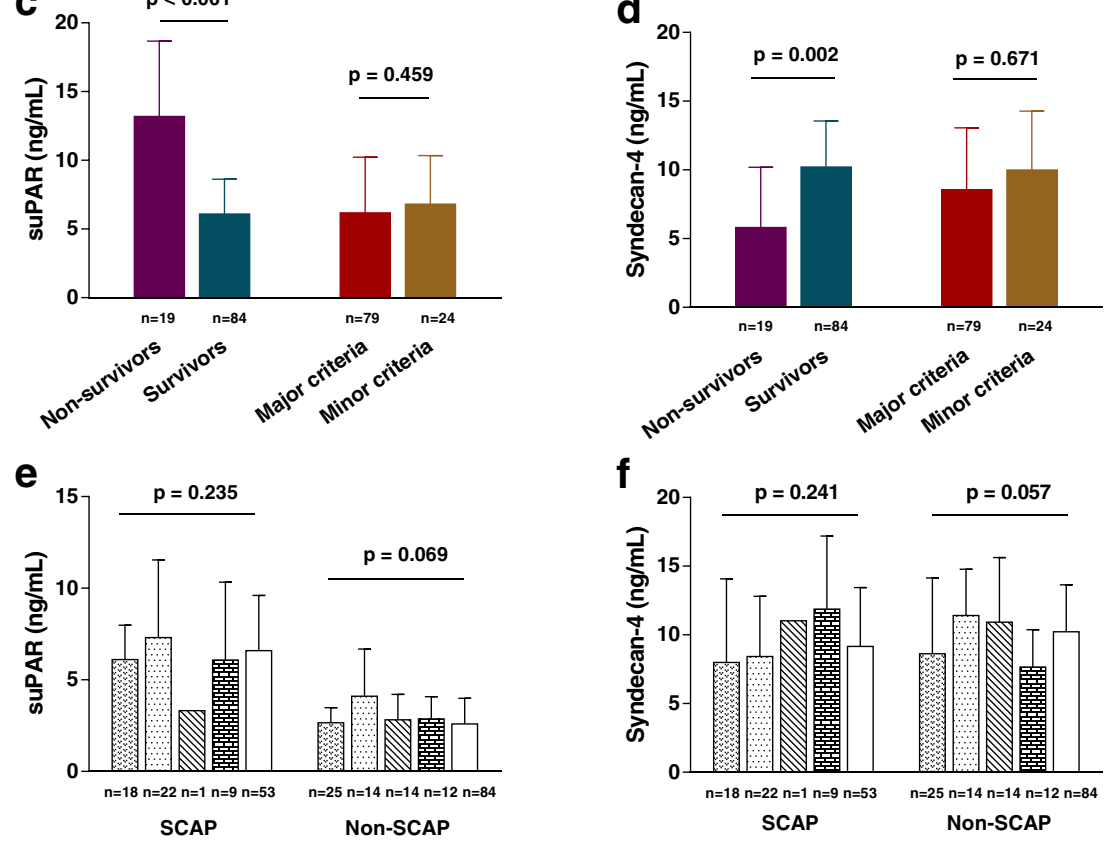

Bacteria $\square$ Virus Atypical pathogen

Fig. 2 Levels of soluble urokinase-type plasminogen activator receptor (suPAR) and syndecan-4 across multiple groups. a, b Levels of suPAR and syndecan-4 in patients with severe community-acquired pneumonia SCAP, patients with non-SCAP, and healthy individuals, respectively. For suPAR, SCAP versus non-SCAP, $p<0.001$; non-SCAP versus healthy individuals, $p<0.001$. For syndecan-4, SCAP versus healthy individuals, $p<0.001$; non-SCAP versus healthy individuals, $p<0.001$. $\mathbf{c}$, d Levels of suPAR and syndecan-4 in survivors and non-survivors among patients with SCAP, patients with SCAP who met at least one major criterion (major criteria), and patients with SCAP who met only minor criterion (minor criteria). For suPAR, survivors versus non-survivors, $p<0.001$; major criteria versus minor criteria, $p=0.459$. For Syndecan-4, survivors versus non-survivors, $p=0.002$; major criteria versus minor criteria, $p=0.671$. e, $\mathbf{f}$ Comparison of suPAR and syndecan-4 in patients with SCAP and non-SCAP for various causative pathogens; $p>0.05$ for all comparisons

$(p=0.177$, data not shown). The expression of syndecan-4 in the non-survivor SCAP group was lower than in the survivor SCAP group $(5.81 \pm 4.38$ and 10.21 $(6.20-13.56) \mathrm{ng} / \mathrm{mL}$, respectively, $p=0.002)$.

In order to avoid possible effects of pre-admission duration of symptoms on the levels of suPAR and syndecan-4, we divided patients in two groups according to the duration of symptoms: $>3$ days or $\leq 3$ days. The expression of suPAR and syndecan-4 was not significantly different between the two groups both in the SCAP and the non-SCAP groups (suPAR, $p=0.549$ (SCAP), $p=0.339$ (non-SCAP); syndecan- $4, p=0.078$ (SCAP), $p=0.635$ (non-SCAP), data not shown). Moreover, the expression of suPAR and syndecan- 4 was not significantly different between patients with SCAP who met at least one major criterion and those who met only minor criteria (suPAR, $p=0.459$; syndecan- $4, p=0.671$ ).

Figure $2 \mathrm{e}$ and $\mathrm{f}$ summarizes the pathogens detected in patients with CAP who were classified as having bacterial, viral, atypical pathogen (including mycoplasma pneumonia, chlamydial pneumonia, and legionella pneumonia), mixed pathogen, and unknown pathogen infections. The causative agent was detected in 50 patients with SCAP and 65 patients with non-SCAP. There were no differences in the levels of suPAR or syndecan-4 between patients with SCAP and patients with nonSCAP who exhibited different causative pathogen infections ( $p>0.05$ for all comparisons). 
Correlation between levels of suPAR and syndecan-4 and the severity of CAP

We chose the CURB-65, PSI, and APACHE II scoring systems to evaluate the severity of CAP. Using our entire sample of 252 patients with CAP, serum suPAR level was positively correlated with all three scoring systems: CURB-65, PSI, and APACHE II $(r=$ $0.399, r=0.433$, and $r=0.496$, respectively; $p<0.001$ for all comparisons; Fig. 3). In addition, suPAR levels were also positively correlated with WBC $(r=0.232$, $p<0.001)$, NLR $(r=0.351, p<0.001)$, CRP $(r=$ $0.272, p<0.001)$, and PCT $(r=0.407, p<0.001)$; SUPAR levels were not positively correlated with age $(r=0.102, p=0.107)$.
Conversely, syndecan-4 levels in patients with CAP were negatively correlated with all three scoring systems: CURB-65 ( $r=-0.220, p=0.001)$, PSI $(r=-0.279, p<$ $0.001)$, and APACHE II $(r=-0.184, p=0.003)$ (Fig. 3). Syndecan-4 levels were also negatively correlated with PCT $(r=-0.304, p<0.001)$, but not with WBC $(r=$ $0.005, p=0.943), \operatorname{NLR}(r=-0.067, p=0.326)$, CRP $(r=-0.127, p=0.081)$, or age $(r=0.023, p=0.719)$.

\section{Value of suPAR and syndecan-4 in predicting SCAP in} patients with CAP

Figure 4 and Table 2 show that suPAR reliably predicted SCAP in patients with CAP, with an AUC of $0.835(p<0.001)$; further, suPAR prediction capability
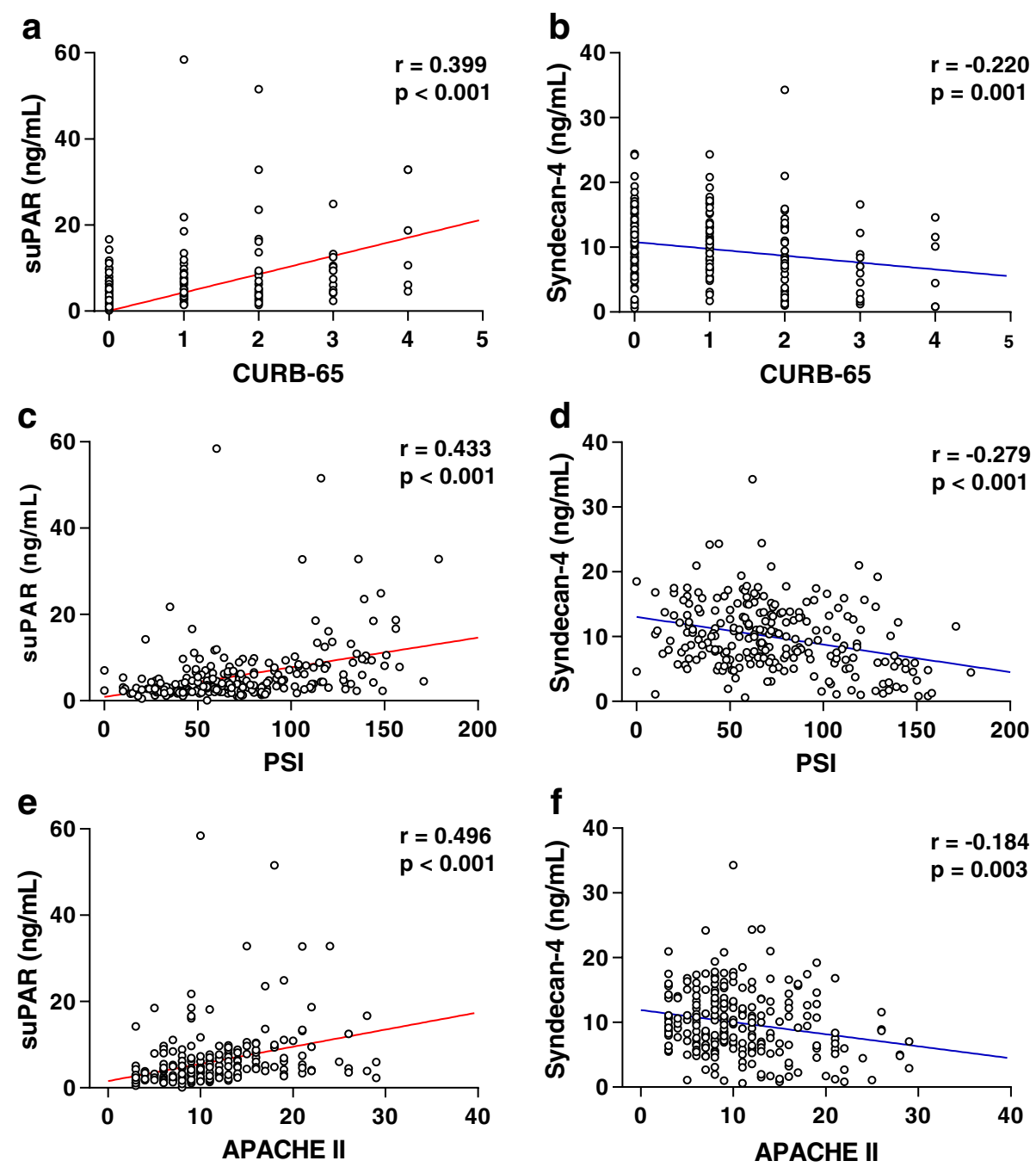

Fig. 3 Correlation of soluble urokinase-type plasminogen activator receptor (suPAR) and syndecan-4 levels with multiple scoring systems across 252 patients with community-acquired pneumonia (CAP). $r$ is the correlation coefficient. $\mathbf{a}, \mathbf{c}$, e Levels of suPAR were significantly positively correlated with the confusion, urea, respiratory rate, blood pressure, and age $\geq 65$ years old (CURB-65) score $(r=0.399, p<0.001)$, Pneumonia Severity Index (PSI) $(r=0.433, p<0.001)$, and Acute Physiology and Chronic Health Evaluation II (APACHE II) score $(r=0.496, p<0.001)$, respectively. $\mathbf{b}, \mathbf{d}$, $\mathbf{f}$ Levels of syndecan-4 were significantly negatively correlated with CURB-65 score $(r=-0.220, p=0.001), \mathrm{PSI}(r=-0.279, p<0.001)$, and APACHE $\|$ score $(r=-0.184, p=0.003)$, respectively 


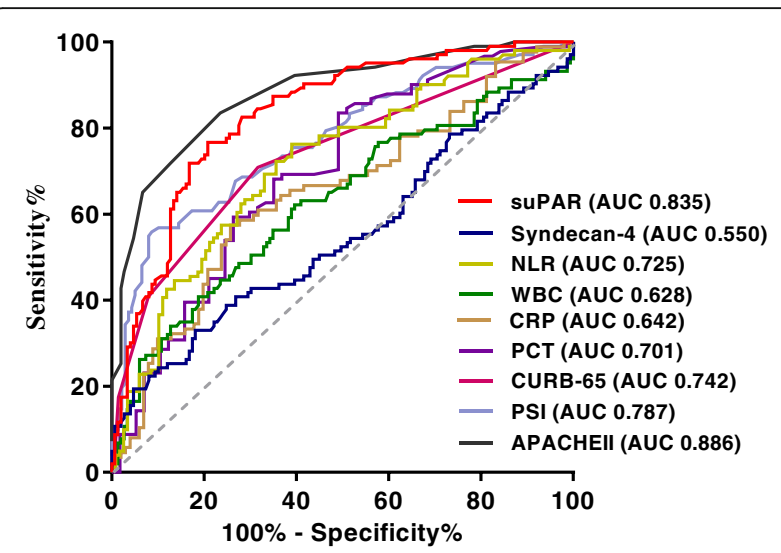

Fig. 4 Receiver operating characteristic curve analysis of various parameters to discriminate patients with severe communityacquired pneumonia from patients with community-acquired pneumonia. SUPAR soluble urokinase-type plasminogen activator receptor, NLR neutrophil/lymphocyte ratio, WBC whole blood leukocyte count, CRP C-reactive protein, $P C T$ procalcitonin, CURB-65 confusion, urea, respiratory rate, blood pressure, and age $\geq 65$ years old score, PSI Pneumonia Severity Index Score, APACHE II Acute Physiology and Chronic Health Evaluation II score, AUC area under the curve

was second only to the APACHE II score (AUC $0.886, p<0.001)$. Using a suPAR threshold value of $4.33 \mathrm{ng} / \mathrm{mL}$ for diagnosis of SCAP, the sensitivity and specificity for discriminating SCAP and CAP were $76.70 \%$ and $79.19 \%$, respectively. Using an APACHE II score $>10$ as a threshold for diagnosis, the sensitivity and specificity for discriminating SCAP from CAP were $78.64 \%$ and $82.55 \%$, respectively. Syndecan-4 was the least accurate in predicting SCAP, with an AUC of 0.550 (not statistically different, $p=0.187$ ). Detailed results are shown in Fig. 4 and Table 2.

\section{Prognostic value of suPAR and syndecan-4 in patients with SCAP}

The ability of suPAR and syndecan- 4 to predict total mortality in patients with SCAP is summarized in Table 3. Notably, the AUCs for suPAR and PSI score were 0.772 and 0.787 , respectively ( $p<0.001$ for both comparisons). The optimal threshold to predict death was $10.22 \mathrm{ng} / \mathrm{mL}$ of suPAR, with a sensitivity of $68.23 \%$ and specificity of $89.29 \%$. While patients with syndecan-4 concentrations $<6.68 \mathrm{ng} / \mathrm{mL}$ exhibited a noticeable increase in risk of death, this threshold yielded sensitivity and specificity of $73.68 \%$ and $71.43 \%$, respectively for prediction of total mortality. The remaining variables, WBC, NLR, CRP, and PCT, had no prognostic value for mortality prediction in patients with SCAP (all $p>0.05$ ).

The combination of suPAR, syndecan-4, and PSI was the most accurate predictor of 30-day mortality, with an AUC of 0.885 . The AUC of the combination of suPAR, syndecan- 4 and CURB-65, and of suPAR, syndecan- 4 and APACHE II score was 0.878 and 0.881, respectively (Fig. 5).

Kaplan-Meier curves were used to assess the relationship between suPAR and syndecan- 4 levels in the prediction of 30-day mortality in patients with SCAP (Fig. 6). Consistent with the prediction threshold for total mortality, the optimal threshold values for 30-day mortality were also $10.22 \mathrm{ng} / \mathrm{mL}$ for suPAR $(p<0.001)$ and $6.68 \mathrm{ng} / \mathrm{mL}$ for syndecan $-4(p<0.001)$.

In univariate Cox proportional hazards regression analysis to determine 30-day survival, suPAR levels $\geq 10.22 \mathrm{ng} / \mathrm{mL}$ and APACHE II scores $>14$ were associated with significantly higher risk ratios than any other variables. In multivariate Cox proportional hazards regression, only suPAR levels $\geq 10.22 \mathrm{ng} / \mathrm{mL}$ and syndecan-4 levels $\leq 6.68 \mathrm{ng} / \mathrm{mL}$ were strong, independent predictors of 30-day survival. Results are summarized in Table 4.

Table 2 Area under the curve (AUC) and thresholds for predicting SCAP in patients with CAP

\begin{tabular}{|c|c|c|c|c|c|c|c|}
\hline & \multirow[t]{2}{*}{ Threshold } & \multirow[t]{2}{*}{ Sensitivity (\%) } & \multirow[t]{2}{*}{ Specificity (\%) } & \multirow[t]{2}{*}{ AUC } & \multirow[t]{2}{*}{$p$ value } & \multicolumn{2}{|l|}{$95 \% \mathrm{Cl}$} \\
\hline & & & & & & Lower limit & Higher limit \\
\hline suPAR (ng/mL) & $>4.33$ & $76.70 \%$ & $79.19 \%$ & 0.835 & $<0.001$ & 0.783 & 0.878 \\
\hline Syndecan-4 (ng/mL) & $\leq 6.10$ & $33.01 \%$ & $81.88 \%$ & 0.550 & 0.187 & 0.487 & 0.613 \\
\hline WBC $\left(\times 10^{9} / L\right)$ & $>12.15$ & $41.75 \%$ & $79.19 \%$ & 0.628 & 0.001 & 0.565 & 0.687 \\
\hline NLR & $>5.61$ & $76.24 \%$ & $61.02 \%$ & 0.725 & $<0.001$ & 0.661 & 0.783 \\
\hline CRP (mg/L) & $>90.48$ & $56.32 \%$ & $73.27 \%$ & 0.642 & 0.001 & 0.569 & 0.710 \\
\hline $\mathrm{PCT}(\mu \mathrm{g} / \mathrm{L})$ & $>0.48$ & $53.85 \%$ & $75.44 \%$ & 0.701 & $<0.001$ & 0.620 & 0.773 \\
\hline CURB-65 & $>0$ & $70.87 \%$ & $68.35 \%$ & 0.742 & $<0.001$ & 0.682 & 0.796 \\
\hline PSI & $>87$ & $56.86 \%$ & $92.03 \%$ & 0.787 & $<0.001$ & 0.729 & 0.837 \\
\hline APACHE ॥ & $>10$ & $78.64 \%$ & $82.55 \%$ & 0.886 & $<0.001$ & 0.840 & 0.923 \\
\hline
\end{tabular}

$S C A P$ severe community-acquired pneumonia, CAP community-acquired pneumonia, suPAR soluble urokinase-type plasminogen activator receptor, WBC whole blood leukocyte count, NLR neutrophil/lymphocyte ratio, CRP C-reactive protein, $P C T$ procalcitonin, CURB-65 confusion, urea, respiratory rate, blood pressure, and age $\geq 65$ years old score, PSI Pneumonia Severity Index score, APACHE II Acute Physiology and Chronic Health Evaluation II score 
Table 3 Area under the curve (AUC) and thresholds for predicting total mortality in patients with SCAP

\begin{tabular}{|c|c|c|c|c|c|c|c|}
\hline & \multirow[t]{2}{*}{ Threshold } & \multirow{2}{*}{$\begin{array}{l}\text { Sensitivity } \\
\text { (\%) }\end{array}$} & \multirow{2}{*}{$\begin{array}{l}\text { Specificity } \\
\text { (\%) }\end{array}$} & \multirow[t]{2}{*}{ AUC } & \multirow{2}{*}{$\begin{array}{l}p \\
\text { value }\end{array}$} & \multicolumn{2}{|l|}{$95 \% \mathrm{Cl}$} \\
\hline & & & & & & Lower limit & Higher limit \\
\hline suPAR (ng/mL) & $\geq 10.22$ & $68.23 \%$ & $89.29 \%$ & 0.772 & $<0.001$ & 0.636 & 0.908 \\
\hline Syndecan-4 (ng/mL) & $\leq 6.68$ & $73.68 \%$ & $71.43 \%$ & 0.744 & $<0.001$ & 0.618 & 0.870 \\
\hline WBC $\left(\times 10^{9} / L\right)$ & $>16.40$ & $36.84 \%$ & $83.33 \%$ & 0.558 & 0.489 & 0.393 & 0.723 \\
\hline NLR & $>15.77$ & $52.63 \%$ & $71.95 \%$ & 0.565 & 0.424 & 0.405 & 0.726 \\
\hline CRP (mg/L) & $>164.15$ & $42.86 \%$ & $73.97 \%$ & 0.533 & 0.701 & 0.363 & 0.703 \\
\hline $\mathrm{PCT}(\mu \mathrm{g} / \mathrm{L})$ & $>0.34$ & $85.71 \%$ & $41.56 \%$ & 0.618 & 0.137 & 0.462 & 0.774 \\
\hline CURB-65 & $>1$ & $68.42 \%$ & $64.29 \%$ & 0.723 & $<0.001$ & 0.607 & 0.839 \\
\hline PSI & $>113$ & $78.95 \%$ & $75.90 \%$ & 0.787 & $<0.001$ & 0.675 & 0.898 \\
\hline APACHE ॥ & $>14$ & $84.21 \%$ & $60.71 \%$ & 0.743 & $<0.001$ & 0.636 & 0.851 \\
\hline
\end{tabular}

SCAP severe community-acquired pneumonia, sUPAR soluble urokinase-type plasminogen activator receptor, WBC whole blood leukocyte count, NLR neutrophil/ lymphocyte ratio, CRP C-reactive protein, PCT procalcitonin, CURB-65 confusion, urea, respiratory rate, blood pressure, and age $\geq 65$ years old score, $P S I$ Pneumonia Severity Index score, APACHE II Acute Physiology and Chronic Health Evaluation II score

\section{Discussion}

In this prospective study of 252 patients with CAP, there were five major findings: (1) serum suPAR levels increased and syndecan-4 levels decreased in patients with CAP, especially in non-survivors, but the changes were not correlated with pre-admission duration of symptoms or the identity of the causative pathogen; (2) elevated suPAR was positively correlated with severity scores (CURB-65, PSI, and APACHE II), whereas lower syndecan-4 was negatively correlated with these same scores; (3) a suPAR threshold value of $4.33 \mathrm{ng} / \mathrm{mL}$ discriminated SCAP from CAP, with $76.70 \%$ sensitivity and 79.19\% specificity, but syndecan-4 levels did not accurately predict SCAP in patients with CAP; (4) the mortality rate was significantly higher in patients with suPAR and syndecan- 4 levels $\geq 10.22 \mathrm{ng} / \mathrm{mL}$ and $\leq 6.68 \mathrm{ng} / \mathrm{mL}$, respectively, and both serum proteins independently predicted 30-day mortality; and (5) the combination of suPAR and syndecan-4 levels with the clinical severity score significantly improved the accuracy of mortality prediction. Taken together, these results suggest that

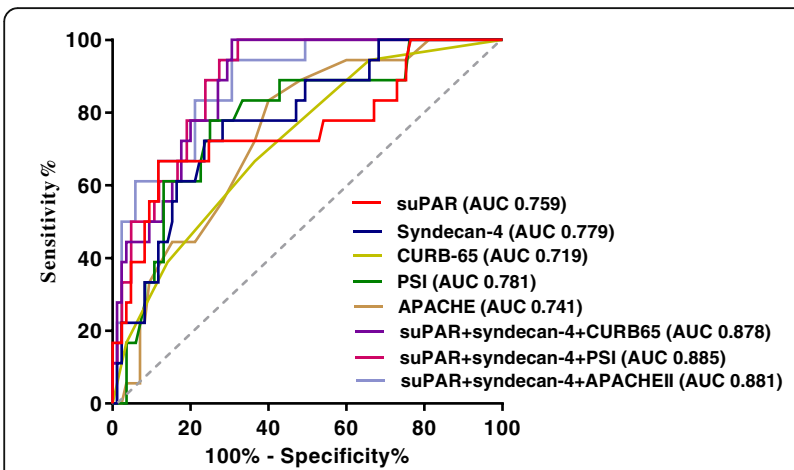

Fig. 5 Receiver operating characteristic (ROC) curve analysis of various parameters to predict 30-day mortality in patients with SCAP

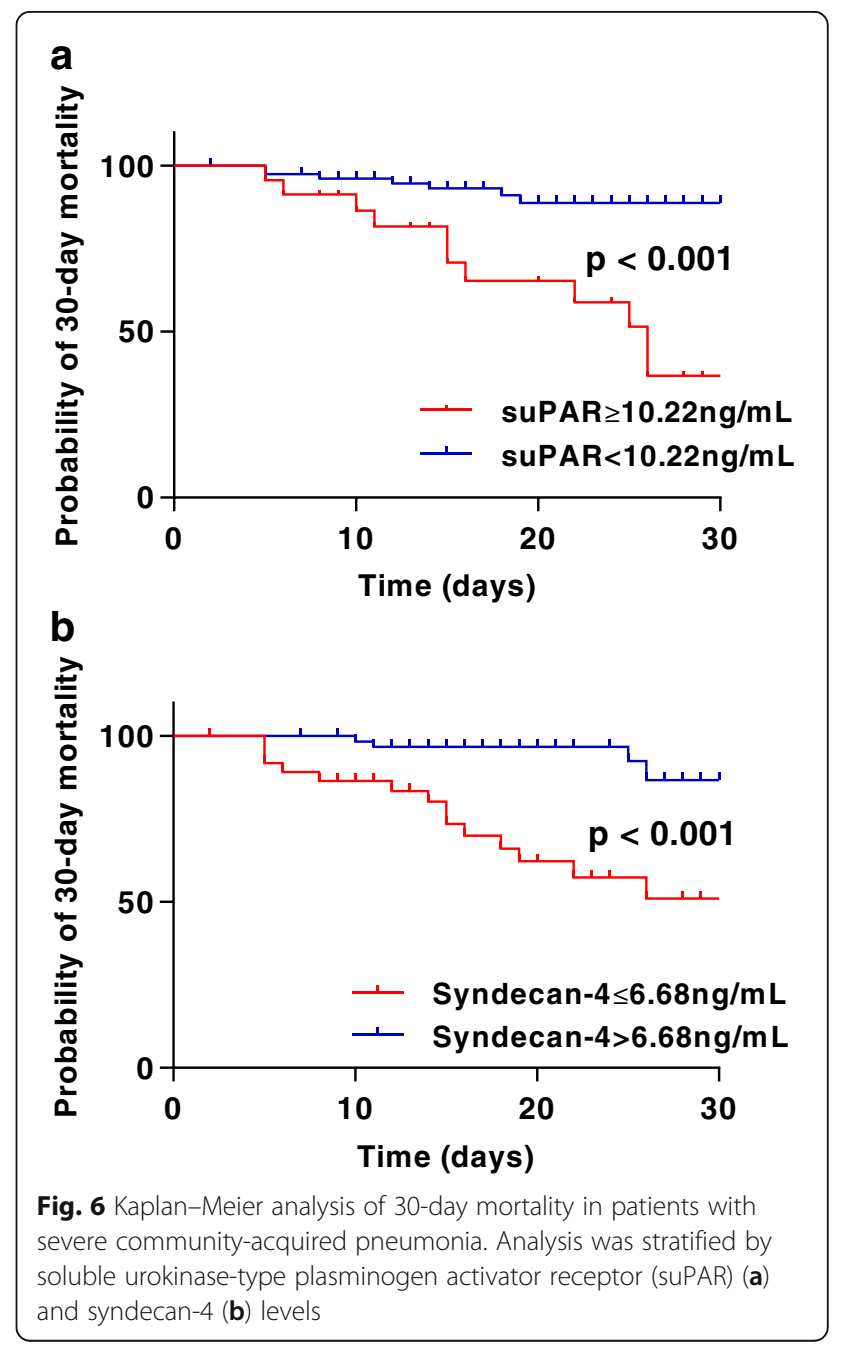


Table 4 Cox proportional hazards regression analysis of the effects of multiple variables on 30-day survival

\begin{tabular}{|c|c|c|c|c|c|}
\hline \multirow[t]{2}{*}{ Variables } & \multicolumn{2}{|l|}{ Univariate analysis } & \multicolumn{3}{|c|}{ Multivariate analysis } \\
\hline & $\mathrm{HR}(95 \% \mathrm{Cl})$ & $p$ value & $\mathrm{HR}(95 \% \mathrm{Cl})$ & & $p$ value \\
\hline Age (>71 years) & 3.709 (1.463-9.405) & 0.006 & & & \\
\hline WBC $\left(>16.40 \times 10^{9} / L\right)$ & $2.560(0.956-6.858)$ & 0.062 & & & \\
\hline NLR $(>15.77)$ & $2.282(0.904-5.759)$ & 0.081 & & & \\
\hline $\mathrm{PCT}(>0.34 \mu \mathrm{g} / \mathrm{L})$ & $4.069(0.901-18.380)$ & 0.068 & & & \\
\hline CURB-65 (>1) & 2.607 (0.977-6.960) & 0.056 & & & \\
\hline PSI (>113) & $5.998(1.967-18.286)$ & 0.002 & & & \\
\hline APACHE $\|(>14)$ & $6.177(1.781-21.419)$ & 0.004 & & & \\
\hline suPAR ( $\geq 10.22 \mathrm{ng} / \mathrm{mL})$ & $7.724(2.887-20.663)$ & $<0.001$ & $8.850(2.716$ & 28.831) & $<0.001$ \\
\hline Syndecan-4 ( $\leq 6.68$ ng/mL) & $5.792(1.901-17.641)$ & 0.002 & $3.976(1.217$ & 12.989) & 0.022 \\
\hline
\end{tabular}

HR hazard ratio, WBC whole blood leukocyte count, NLR neutrophil/lymphocyte ratio, $P C T$ procalcitonin, CURB-65 confusion, urea, respiratory rate, blood pressure, and age $\geq 65$ years old score, PSI Pneumonia Severity Index score, APACHE II Acute Physiology and Chronic Health Evaluation II score, suPAR soluble urokinase-type plasminogen activator receptor

serum suPAR and syndecan-4 levels can predict disease severity in patients with CAP.

suPAR has been widely studied in a variety of infectious diseases, including sepsis [23], tuberculosis [24], and HIV infection [25]. Savva et al. demonstrated that suPAR is a reliable predictor of severity of sepsis and can independently predict unfavourable outcomes in both ventilator-associated pneumonia and sepsis [26]. The findings of our study are identical to previous studies $[26,27]$ where suPAR levels were significantly elevated in patients with SCAP, especially in non-survivors. These results enhance our understanding of the expression of suPAR in severe infections. Furthermore, we found that suPAR levels are not correlated with specific causative agents in the same risk stratification of CAP. This is consistent with a previous study demonstrating that suPAR has no discriminatory value in patients with bacterial, viral, or parasitic infections [28].

Studies on the expression of syndecan-4 in infection are few. Nikaido et al. found that syndecan-4 levels were significantly increased in a study of 30 patients with acute mild pneumonia, and that this protein provides an anti-inflammatory function in acute pneumonia [29]. In contrast, our results show that syndecan-4 levels are significantly lower in patients with CAP compared with healthy individuals; this reduction was more pronounced in non-survivors. The lower syndecan-4 levels in our study may result from the larger sample size and the increase in CAP severity in our study, compared with the previous study. Syndecan-4 expression was elevated in mild acute pneumonia because of bacterial components that stimulated toll-like receptors 2 and 4 [29]. Importantly, the causative mechanism for lowered syndecan-4 levels in patients with CAP is not yet clear. Further, as in the analysis of suPAR, syndecan-4 levels were not statistically different among patients with CAP due to a variety of causative agents.
We investigated the correlation between suPAR and syndecan-4 levels and a variety of clinical parameters. There was strong correlation between levels of suPAR or syndecan-4 and the clinical scoring systems, suggesting that serum suPAR and syndecan-4 might aid in clinical judgment of the degree of severity. Remarkably, there was broad correlation between suPAR levels and a variety of laboratory measures: WBC, NLR, CRP, and PCT. In contrast, Wittenhagen et al. found that suPAR was not correlated with CRP in pneumococcal bacteraemia [27], but these differences may result from different patient samples. The NLR has been reported to indicate mortality and prognosis in various diseases, including tumour [30], inflammation [31], and heart failure [32]. Since NLR is convenient, easily obtained, and low cost, we included NLR as a clinical reference biomarker in this study.

The diagnostic value of suPAR is reportedly poor and was not shown to be superior to CRP or PCT. The AUC for suPAR to discriminate 197 septic ICU patients from 76 non-septic patients is 0.62 [33]. Kofoed et al. measured plasma suPAR levels in 57 patients with systemic inflammatory response syndrome (SIRS), and reported an AUC of 0.54 for suPAR (and 0.81 and 0.72 for CRP and PCT, respectively) in diagnosing bacterial infection [28]. Savva et al. reported an AUC of 0.758 for suPAR to discriminate severe sepsis or patients with septic shock within a group of 180 patients with sepsis; in the same study, the AUC for PCT was 0.652 [26]. Hoenighl et al. reported that in 132 patients with SIRS, the AUC for suPAR and PCT was 0.726 and 0.744 , respectively, to differentiate patients with and without bacteraemia [34]. However, our results indicate that suPAR (AUC 0.835) had good diagnostic value in discriminating SCAP from CAP, which is comparable to APACHE II (AUC 0.886), the "gold standard" criterion for stratifying critically ill patients [22]. Taken together, these studies suggest that suPAR might have better diagnostic value in 
discriminating between severe and mild cases of infectious disease than in discriminating between infectious and non-infectious diseases.

Many studies focus on the prognostic value of suPAR; the AUC for suPAR in predicting in-hospital mortality ranges from 0.67 to 0.84 [35-37]. In our study, the AUC of suPAR to predict mortality was 0.772. Kaplan-Meier curves showed that suPAR $\geq 10.22 \mathrm{ng} / \mathrm{mL}$ was associated with significantly higher mortality risk; this threshold value is identical to at reported in prior studies [35, 38]. Further, in multivariate Cox proportional hazards regression, suPAR was an independent marker to predict 30-day mortality. This indicates that suPAR may provide a promising prognostic biomarker in SCAP.

The mechanism for increased suPAR levels in severely ill patients was uncertain. suPAR is expressed on the surface of various cells, including neutrophils, lymphocytes, macrophages, and endotheliocytes. During an inflammatory response, the presence of increased suPARexpressing cells and the accelerated cleavage of suPAR might result in high blood levels of suPAR [35]. Furthermore, severely ill patients often present with dysfunctional blood coagulation. Excessive cytokine release activates the coagulation system in multiple ways, and contributes to the formation of a complex reaction that includes coagulation, inflammatory mediators, cytokines, and complement [39]. These processes might also promote expression of suPAR.

There has been no report on the diagnostic and prognostic value of syndecan-4. Our results show that although syndecan-4 did not discriminate SCAP from CAP, it might be used to predict mortality in patients with SCAP, with an AUC of 0.744. Further, multivariate Cox regression analysis demonstrated that the syndecan-4 level was an independent factor related to 30-day mortality. Previous studies reported that syndecan-4-deficient mice exhibit significantly higher bacterial counts, more severe pulmonary inflammation, and higher mortality, compared with wild-type mice $[29,40,41]$. Notably, these studies found that syndecan-4 expression was elevated in macrophages, endothelial cells, and epithelial cells after stimulation with lipopolysaccharide in vitro [40, 41].

Although suPAR and syndecan-4 were both good in predicting 30-day mortality, none was better than PSI. Remarkably, our results show that the addition of both suPAR and syndecan- 4 to a clinical severity scoring method significantly improved their prognostic accuracy. The severity score alone is often insufficient to obtain satisfactory predictive accuracy. Therefore, biomarkers are thought to be able to better stratify patients. Mid-region proadrenomedullin (MR-proADM) has been hitherto the best single predictor of short-term and long-term mortality. Notably, the AUC of a combination of MR-
proADM and PSI for 30-day mortality prediction can reach 0.914 [6].

Our study has certain limitations. Only serum suPAR and syndecan-4 levels were detected at the time of admission; dynamic and follow-up changes (in response to treatment) were not investigated. Besides, suPAR is a non-specific inflammatory marker that has been shown to be increased in diabetes mellitus [42], liver disease [43], and heart failure [44]. While our study enrolled a number of patients with those comorbidities (as shown in Table 1), the pre-admission levels of suPAR should be tested. The effects of changes in suPAR and syndecan- 4 expression during the pathogenesis of CAP should be further investigated.

\section{Conclusions}

In conclusion, we demonstrated that serum suPAR is elevated, and serum syndecan-4 is reduced, in patients with SCAP. suPAR is able to accurately predict SCAP and mortality in patients with CAP. Further, we revealed that syndecan- 4 has no diagnostic value but that it can serve as a prognostic biomarker in patients with SCAP. The combination of both suPAR and syndecan-4 with clinical scores significantly improved their 30-day mortality prediction.

\begin{abstract}
Abbreviations
APACHE II: Acute Physiology and Chronic Health Evaluation II; AUC: Area under the curve; CAP: Community-acquired pneumonia; Cl: Confidence interval; CRP: C-reactive protein; CURB-65: Confusion, urea, respiratory rate, blood pressure, and age $\geq 65$ years old, scoring system; MR-proADM: Midregion proadrenomedullin; NLR: Neutrophil/lymphocyte ratio;

PA: Plasminogen activator; PCT: Procalcitonin; pro-ADM: Proadrenomedullin; PSI: Pneumonia Severity Index; ROC: Receiver operating characteristic; SCAP: Severe community-acquired pneumonia; sUPAR: Soluble urokinasetype plasminogen activator receptor; UPAR: Urokinase-type plasminogen activator receptor; WBC: Whole blood leukocyte count
\end{abstract}

\section{Acknowledgements}

The authors thank the following hospitals for their efforts and dedication in enrolling study participants: Peking University People's Hospital, Tianjin Medical University General Hospital, Wuhan University People's Hospital, Fujian Provincial Hospital, and The First Affiliated Hospital of Zhengzhou University.

\section{Funding}

This study was funded by The National Key Research and Development Programme of China (2016YFC0903800).

\section{Availability of data and materials}

The datasets generated and analysed during the current study are not publicly available due to health privacy concerns, but are available from the corresponding author on reasonable request.

\footnotetext{
Authors' contributions

The roles of the authors in this study were as follows: ZC-G conceived this study and obtained research funding. P-N and $\mathrm{YL}-\mathrm{Z}$ were in charge of sample preservation, and reinforced clinical data for the database. Y-S and B-Z provided experimental support. QZ-L conducted biomarker measurements, analysed data, and wrote and edited the manuscript. All authors read and approved the final manuscript.
}

Ethics approval and consent to participate

All subjects provided informed consent. This study was approved by the medical ethics committee of Peking University People's Hospital. 


\section{Consent for publication}

Not applicable.

\section{Competing interests}

The authors declare that they have no competing interests.

\section{Publisher's Note}

Springer Nature remains neutral with regard to jurisdictional claims in published maps and institutional affiliations.

\section{Received: 8 October 2017 Accepted: 4 January 2018}

\section{Published online: 24 January 2018}

\section{References}

1. Prina E, Ranzani OT, Torres A. Community-acquired pneumonia. Lancet. 2015;386:1097-108.

2. Musher DM, Thorner AR. Community-acquired pneumonia. N Engl J Med. 2014;371:1619-28.

3. Chalmers JD. Identifying severe community-acquired pneumonia: moving beyond mortality. Thorax. 2015;70:515-6.

4. Fine MJ, Auble TE, Yealy DM, Hanusa BH, Weissfeld LA, Singer DE, Coley CM, Marrie TJ, Kapoor WN. A prediction rule to identify low-risk patients with community-acquired pneumonia. N Engl J Med. 1997;336:243-50.

5. Gibot S, Cravoisy A, Levy B, Bene MC, Faure G, Bollaert PE. Soluble triggering receptor expressed on myeloid cells and the diagnosis of pneumonia. $\mathrm{N}$ Engl J Med. 2004;350:451-8.

6. Bello S, Lasierra AB, Mincholé E, Fandos S, Ruiz MA, Vera E, de Pablo F, Ferrer M, Menendez R, Torres A. Prognostic power of proadrenomedullin in community-acquired pneumonia is independent of aetiology. Eur Respir J. 2012;39:1144-55.

7. Krüger S, Ewig S, Giersdorf S, Hartmann O, Suttorp N, Welte T; German Competence Network for the Study of Community Acquired Pneumonia (CAPNETZ) Study Group. Cardiovascular and inflammatory biomarkers to predict short- and long-term survival in community-acquired pneumonia: Results from the German Competence Network, CAPNETZ. Am J Respir Crit Care Med. 2010;182:1426-34.

8. Manetti M, Rosa I, Milia AF, Guiducci S, Carmeliet P, Ibba-Manneschi L, Matucci-Cerinic M. Inactivation of urokinase-type plasminogen activator receptor (UPAR) gene induces dermal and pulmonary fibrosis and peripheral microvasculopathy in mice: a new model of experimental scleroderma? Ann Rheum Dis. 2014;73:1700-9.

9. Kobayashi N, Ueno T, Ohashi K, Yamashita H, Takahashi Y, Sakamoto K, Manabe S, Hara S, Takashima Y, Dan T, Pastan I, Miyata T, Kurihara H, Matsusaka T, Reiser J, Nagata M. Podocyte injury-driven intracapillary plasminogen activator inhibitor type 1 accelerates podocyte loss via UPARmediated $\beta 1$-integrin endocytosis. Am J Physiol Renal Physiol. 2015;308: F614-26.

10. Genua M, D'Alessio S, Cibella J, Gandelli A, Sala E, Correale C, Spinelli A, Arena V, Malesci A, Rutella S, Ploplis VA, Vetrano S, Danese S. The urokinase plasminogen activator receptor (UPAR) controls macrophage phagocytosis in intestinal inflammation. Gut. 2015;64:589-600.

11. Mazzieri R, Pietrogrande G, Gerasi L, Gandelli A, Colombo P, Moi D, Brombin C, Ambrosi A, Danese S, Mignatti P, Blasi F, D'Alessio S. Urokinase receptor promotes skin tumor formation by preventing epithelial cell activation of Notch1. Cancer Res. 2015;75:4895-909.

12. Matzkies LM, Raggam RB, Flick H, Rabensteiner J, Feierl G, Hoenigl M, Prattes J. Prognostic and diagnostic potential of suPAR levels in pleural effusion. J Infect. 2017;75:465-7.

13. Donadello K, Covajes C, Covajes C, Vincent JL. suPAR as a prognostic biomarker in sepsis. BMC Med. 2012;10:2.

14. Choi S, Chung H, Hong H, Kim SY, Kim SE, Seoh JY, Moon CM, Yang EG, Oh ES. Inflammatory hypoxia induces syndecan-2 expression through IL-1 $\beta$-mediated FOXO3a activation in colonic epithelia. FASEB J. 2017;31:1516-30.

15. Brauer R, Ge L, Schlesinger SY, Birkland TP, Huang Y, Parimon T, Lee V, McKinney BL, McGuire JK, Parks WC, Chen P. Syndecan-1 attenuates lung injury during influenza infection by potentiating c-met signaling to suppress epithelial apoptosis. Am J Respir Crit Care Med. 2016;194:333-44.

16. Cassinelli G, Zaffaroni N, Lanzi C. The heparanase/heparan sulfate proteoglycan axis: a potential new therapeutic target in sarcomas. Cancer Lett. 2016;382:245-54.
17. Santoso A, Kikuchi T, Tode N, Hirano T, Komatsu R, Damayanti T, Motohashi $\mathrm{H}$, Yamamoto M, Kojima T, Uede T, Nukiwa T, Ichinose M. Syndecan 4 mediates Nrf2-dependent expansion of bronchiolar progenitors that protect against lung inflammation. Mol Ther. 2016;24:41-52.

18. Niederman MS, Mandell LA, Anzueto A, Bass JB, Broughton WA, Campbell GD, Dean N, File T, Fine MJ, Gross PA, Martinez F, Marrie TJ, Plouffe JF, Ramirez J, Sarosi GA, Torres A, Wilson R, Yu VL; American Thoracic Society. Guidelines for the management of adults with community-acquired pneumonia. Diagnosis, assessment of severity, antimicrobial therapy, and prevention. Am J Respir Crit Care Med. 2001;163:1730-54.

19. Mandell LA, Wunderink RG, Anzueto A, Bartlett JG, Campbell GD, Dean NC, Dowell SF, File TM Jr, Musher DM, Niederman MS, Torres A, Whitney CG; Infectious Diseases Society of America; American Thoracic Society. Infectious Diseases Society of America/American Thoracic Society consensus guidelines on the management of community-acquired pneumonia in adults. Clin Infect Dis. 2007:44 Suppl 2:S27-72.

20. Capelastegui A, España PP, Quintana JM, Areitio I, Gorordo I, Egurrola M, Bilbao A. Validation of a predictive rule for the management of communityacquired pneumonia. Eur Respir J. 2006;27:151-7.

21. Spindler C, Ortqvist A. Prognostic score systems and community-acquired bacteraemic pneumococcal pneumonia. Eur Respir J. 2006:28:816-23.

22. Knaus WA, Draper EA, Wagner DP, Zimmerman JE. APACHE II: a severity of disease classification system. Crit Care Med. 1985;13:818-29.

23. Giamarellos-Bourboulis EJ, Norrby-Teglund A, Mylona V, Savva A, Tsangaris I, Dimopoulou I, Mouktaroudi M, Raftogiannis M, Georgitsi M, Linnér A, Adamis G, Antonopoulou A, Apostolidou E, Chrisofos M, Katsenos C, Koutelidakis I, Kotzampassi K, Koratzanis G, Koupetori M, Kritselis I, Lymberopoulou K, Mandragos K, Marioli A, Sundén-Cullberg J, Mega A, Prekates A, Routsi C, Gogos C, Treutiger CJ, Armaganidis A, Dimopoulos G. Risk assessment in sepsis: a new prognostication rule by APACHE II score and serum soluble urokinase plasminogen activator receptor. Crit Care. 2012;16(4):R149.

24. Rudolf F, Wagner AJ, Back FM, Gomes VF, Aaby P, Østergaard L, EugenOlsen J, Wejse C. Tuberculosis case finding and mortality prediction: added value of the clinical TBscore and biomarker suPAR. Int J Tuberc Lung Dis. 2017;21:67-72.

25. Rasmussen LJ, Knudsen A, Katzenstein TL, Gerstoft J, Obel N, Jørgensen NR, Kronborg G, Benfield T, Kjaer A, Eugen-Olsen J, Lebech AM. Soluble urokinase plasminogen activator receptor (suPAR) is a novel, independent predictive marker of myocardial infarction in HIV-1-infected patients: a nested case-control study. HIV Med. 2016;17:350-7.

26. Savva A, Raftogiannis M, Baziaka F, Routsi C, Antonopoulou A, Koutoukas P, Tsaganos T, Kotanidou A, Apostolidou E, Giamarellos-Bourboulis EJ, Dimopoulos G. Soluble urokinase plasminogen activator receptor (suPAR) for assessment of disease severity in ventilator-associated pneumonia and sepsis. J Infect. 2011;63:344-50.

27. Wittenhagen P, Kronborg G, Weis N, Nielsen H, Obel N, Pedersen SS, EugenOlsen J. The plasma level of soluble urokinase receptor is elevated in patients with Streptococcus pneumoniae bacteraemia and predicts mortality. Clin Microbiol Infect. 2004;10:409-15.

28. Kofoed K, Andersen O, Kronborg G, Tvede M, Petersen J, Eugen-Olsen J, Larsen K. Use of plasma C-reactive protein, procalcitonin, neutrophils, macrophage migration inhibitory factor, soluble urokinase-type plasminogen activator receptor, and soluble triggering receptor expressed on myeloid cells-1 in combination to diagnose infections: a prospective study. Crit Care. 2007;11:R38

29. Nikaido T, Tanino Y, Wang X, Sato S, Misa K, Fukuhara N, Sato Y, Fukuhara A, Uematsu M, Suzuki Y, Kojima T, Tanino M, Endo Y, Tsuchiya K, Kawamura I, Frevert CW, Munakata M. Serum syndecan-4 as a possible biomarker in patients with acute pneumonia. J Infect Dis. 2015; 212:1500-8.

30. Derman BA, Macklis JN, Azeem MS, Sayidine S, Basu S, Batus M, Esmail F, Borgia JA, Bonomi P, Fidler MJ. Relationships between longitudinal neutrophil to lymphocyte ratios, body weight changes, and overall survival in patients with non-small cell lung cancer. BMC Cancer. 2017;17:141.

31. Curbelo J, Luquero Bueno S, Galván-Román JM, Ortega-Gómez M, Rajas $O$, Fernández-Jiménez $G$, Vega-Piris $L$, Rodríguez-Salvanes $F$, Arnalich $B$, Díaz A, Costa R, de la Fuente H, Lancho Á, Suárez C, Ancochea J, Aspa J. Inflammation biomarkers in blood as mortality predictors in 
community-acquired pneumonia admitted patients: Importance of comparison with neutrophil count percentage or neutrophil-lymphocyte ratio. PLoS One. 2017;12, e0173947.

32. Benites-Zapata VA, Hernandez AV, Nagarajan V, Cauthen CA, Starling RC, Tang WH. Usefulness of neutrophil-to-lymphocyte ratio in risk stratification of patients with advanced heart failure. Am J Cardiol. 2015;115:57-61.

33. Koch A, Voigt S, Kruschinski C, Sanson E, Dückers H, Horn A, Yagmur E, Zimmermann H, Trautwein C, Tacke F. Circulating soluble urokinase plasminogen activator receptor is stably elevated during the first week of treatment in the intensive care unit and predicts mortality in critically ill patients. Crit Care. 2011;15:R63.

34. Hoenigl M, Raggam RB, Wagner J, Valentin T, Leitner E, Seeber K, ZollnerSchwetz I, Krammer W, Prüller F, Grisold AJ, Krause R. Diagnostic accuracy of soluble urokinase plasminogen activator receptor (suPAR) for prediction of bacteremia in patients with systemic inflammatory response syndrome. Clin Biochem. 2013;46:225-9.

35. Suberviola B, Castellanos-Ortega A, Ruiz Ruiz A, Lopez-Hoyos M, Santibañez M. Hospital mortality prognostication in sepsis using the new biomarkers sUPAR and proADM in a single determination on ICU admission. Intensive Care Med. 2013;39:1945-52.

36. Mölkänen $T$, Ruotsalainen $E$, Thorball CW, Järvinen A. Elevated soluble urokinase plasminogen activator receptor (sUPAR) predicts mortality in Staphylococcus aureus bacteremia. Eur J Clin Microbiol Infect Dis. 2011; 30:1417-24

37. Huttunen R, Syrjänen J, Vuento R, Hurme M, Huhtala H, Laine J, Pessi T, Aittoniemi J. Plasma level of soluble urokinase-type plasminogen activator receptor as a predictor of disease severity and case fatality in patients with bacteraemia: a prospective cohort study. J Intern Med. 2011;270:32-40.

38. Jalkanen V, Yang R, Linko R, Huhtala H, Okkonen M, Varpula T, Pettilä V, Tenhunen J, FINNALI Study Group. SuPAR and PAI-1 in critically ill, mechanically ventilated patients. Intensive Care Med. 2013;39:489-96.

39. Murciano JC, Higazi AA, Cines DB, Muzykantov VR. Soluble urokinase receptor conjugated to carrier red blood cells binds latent pro-urokinase and alters its functional profile. J Control Release. 2009;139:190-6.

40. Tanino Y, Chang MY, Wang X, Gill SE, Skerrett S, McGuire JK, Sato S, Nikaido T, Kojima T, Munakata M, Mongovin S, Parks WC, Martin TR, Wight TN, Frevert CW. Syndecan-4 regulates early neutrophil migration and pulmonary inflammation in response to lipopolysaccharide. Am J Respir Cell Mol Biol. 2012:47:196-202.

41. Ishiguro K, Kadomatsu K, Kojima T, Muramatsu H, Iwase M, Yoshikai Y, Yanada M, Yamamoto K, Matsushita T, Nishimura M, Kusugami K, Saito H, Muramatsu T. Syndecan-4 deficiency leads to high mortality of lipopolysaccharide-injected mice. J Biol Chem. 2001;276:47483-8.

42. Theilade S, Lyngbaek S, Hansen TW, Eugen-Olsen J, Fenger M, Rossing P, Jeppesen JL. Soluble urokinase plasminogen activator receptor levels are elevated and associated with complications in patients with type 1 diabetes. J Intern Med. 2015;277:362-71.

43. Kirkegaard-Klitbo DM, Langkilde A, Mejer N, Andersen O, Eugen-Olsen J, Benfield T. Soluble urokinase plasminogen activator receptor is a predictor of incident non-AIDS comorbidity and all-cause mortality in human immunodeficiency virus type 1 infection. J Infect Dis. 2017;216:819-23.

44. Koller L, Stojkovic S, Richter B, Sulzgruber P, Potolidis C, Liebhart F, Mörtl D, Berger R, Goliasch G, Wojta J, Hülsmann M, Niessner A. Soluble urokinasetype plasminogen activator receptor improves risk prediction in patients with chronic heart failure. JACC Heart Fail. 2017:5:268-77.

\section{Submit your next manuscript to BioMed Central and we will help you at every step:}

- We accept pre-submission inquiries

- Our selector tool helps you to find the most relevant journal

- We provide round the clock customer support

- Convenient online submission

- Thorough peer review

- Inclusion in PubMed and all major indexing services

- Maximum visibility for your research

Submit your manuscript at www.biomedcentral.com/submit 